\title{
EDITORIAL
}

\section{The Relevance of Scientific Journals in the Dissemination of Knowledge}

\begin{abstract}
Exploring the surrounding world, seeking answers to the problems that human beings face every day is one of their innate conditions, and there, precisely, there is an urgent need to reflect continuously and systematically spending time searching for new information.
\end{abstract}

In a nutshell, the core of scientific research presupposes the exploration of replicas, answers, refutations, trying to establish a connection with reality, achieving complete knowledge to contribute to the social, economic and cultural progress of the people.

From that point of view, then, it could be affirmed that research is an intellectual activity based on the curiosity of people and, consequently, a work of reflexive, methodical and highly critical thinking individuals.

In the current times, society expects universities to assume and install as a priority the task of research as one of its most representative pillars; although this does not mean that there is no awareness that it will not necessarily be possible to satisfy all the concerns of the community, since most of the time probable answers are offered after the scientific inquiry process is operationalized.

In its vast majority, the results of the research translate into scientific publications in indexed journals. Currently, for example, the Scimago database includes more than 34 thousand journals indexed in Scopus, and only $2.46 \%$ are from Latin America. This scenario that is repeated with scientific articles; In 2018, $3,536,878$ were published worldwide, of which only 149,895 were generated in the Region (Scimago, 2018).

Now, if we consider the production by countries, Scimago itself has prepared a production ranking with one hundred countries, which is led by the United States, with 683,003 documents; and ten countries (in addition to the US, China, United Kingdom, Germany, India, Japan, France, Italy, Canada, and Australia), account for $61.7 \%$ of the total articles (Scimago, 2018).

In the case of Latin America, Brazil occupies the best position in fourteenth place with a figure of 81,742, followed by Mexico with 25,290 and Argentina with 14,737 in the twenty-eighth and forty-fourth positions respectively. Nevertheless, the sum of the scientific production of the Region constitutes only $4.19 \%$ of the total worldwide.

If the analysis is carried out by disciplinary areas, it is possible to determine that in the Engineering (miscellaneous) category, in Scopus there are 474 scientific journals and only nine are Latin American (four Colombian, two Brazilian, one Chilean, one Mexican and one Venezuelan); none is Q1, four are Q2, and three are Q3 (Scimago, 2018).

These are some of the reasons that fully justify the support of Latin American universities and their respective governments, to scientific journals, which must be strengthened to improve their international positioning in the relevant quality indexes. We must never forget that it is through scientific publications, that society can appreciate and become aware of the results of research work and what it represents for the respective community, which is who finally funds the scientific activity.

Francisco Ganga-Contreras, PhD. Universidad de Los Lagos Santiago, Chile E-mail: fganga@ulagos.cl 
EDITORIAL

\section{Relevancia de las revistas científicas en la difusión del conocimiento}

Escudriñar el mundo circundante, buscar respuestas a los problemas que cotidianamente afronta el ser humano es una de sus condiciones innatas y ahí, precisamente, se suscita la urgencia de reflexionar continua y sistemáticamente y dedicar tiempo a la búsqueda de nueva información.

Dicho en pocas palabras, la "médula central" de la investigación científica presupone la exploración de réplicas, contestaciones, refutaciones; junto con el anhelo permanente de intentar establecer conexión con la realidad y lograr un conocimiento más acabado con el ánimo de aportar al progreso social, económico y cultural de los pueblos.

Bajo esa óptica, entonces, se pudiese afirmar que la investigación es una actividad intelectual basada en la curiosidad de las personas y, por consiguiente, una labor propia de individuos reflexivos, metódicos y con pensamiento crítico.

En los tiempos que corren, la sociedad espera que las universidades asuman e instalen prioritariamente la tarea de investigar como uno de sus pilares más representativos; aunque ello no signifique que no se tenga conciencia de que no necesariamente se conseguirán satisfacer todas las inquietudes de la Comunidad, pues la mayoría de las veces se ofrecen respuestas probables luego de operacionalizado el proceso de indagación científica.

Es importante subrayar, que en su inmensa mayoría, los resultados de las investigaciones se traducen en publicaciones científicas en revistas indexadas. Actualmente, por ejemplo, la base de datos de Scimago incluye más de 34 mil revistas indexadas en Scopus y sólo el 2,46\% son de América Latina. Escenario que se repite con los artículos científicos; en 2018 se publicaron 3.536 .878 en el mundo, de los cuales exclusivamente 149.895 fueron generados en la Región (Scimago, 2018).

Ahora bien, si consideramos la producción por países, el mismo Scimago ha confeccionado un ranking de producción con cien países, el cual aparece liderado por Estados Unidos, con 683.003 documentos; y diez países (además de EEUU, China, Reino Unido, Alemania, India, Japón, Francia, Italia, Canadá y Australia), concentran el 61,7\% del total de artículos (Scimago, 2018).

En el caso de América Latina, la mejor posición la ocupa Brasil en el decimocuarto lugar con una cifra de 81.742, seguido de México con 25.290 y Argentina con 14.737 en el vigésimo octavo y cuadragésimo cuarto puestos respectivamente. No obstante, la suma de la producción científica de la Región constituye únicamente el $4,19 \%$ del total a nivel mundial.

Si el análisis se realiza por áreas disciplinarias es posible determinar que en la categoría Engineering (miscellaneous), en Scopus existen 474 revistas científicas y sólo nueve son latinoamericanas (cuatro colombianas, dos brasileñas, una chilena, una mexicana y una venezolana); ninguna es Q1, cuatro son Q2 y tres son Q3 (Scimago, 2018).

Estas son algunas de las razones que justifican plenamente el soporte que deben darle las universidades latinoamericanas y sus respectivos gobiernos y el Estado, a las revistas científicas, las que deben ser fortalecidas para mejorar su posicionamiento internacional en los concernientes índices de calidad. Nunca olvidarse que es a través de una publicación científica, que la sociedad puede conocer y tomar conciencia de los resultados de un trabajo de investigación y lo que representa para la respectiva comunidad, que es la que finalmente financia la actividad científica.

Dr. Francisco Ganga-Contreras

Universidad de Los Lagos

Santiago, Chile

E-mail: fganga@ulagos.cl 